was opened by Mr. J. Wickham Murray, who outlined some of the work of the Union in developing contacts between Britain and America. He specially stressed schemes such as the Page Scholarships scheme for men and women teachers, reciprocal scholarships under American direction, exchange of school boys and school masters and mistresses, and assistance given to visitors in both countries. $\mathrm{He}$ indicated, however, that the Union desires now to widen its work and to face the greater responsibilities which the present state of the world suggests it should undertake. To that end it has formed a Research and Discussion Committee, which is seeking the advice and guidance of experts in such fields as foreign affairs, economics, the Press of both countries, and general relationships such as would arise as a result of neutrality legislation and American grievances against British policy. Already meetings of experts in these matters have been held, and, at every meeting, the importance of closer attention to matters of education has been stressed.

Mr. Wickham Murray added that, in thinking it important for British students at school and university to get an accurate picture of Englishspeaking countries, the Union believes that because of similarities in our joint democratic institutions, experiments in those countries might be of greater relevance to Britain than experiments in such very different countries as Soviet Russia, Italy or Germany. In asking the meeting to consider what might be done to improve the contribution of British educational bodies so far as an understanding of problems in English-speaking countries is concerned, he raised the question of possible changes in examination syllabuses, special facilities for providing books on American and Dominion history and affairs, the increase of scholarships and fellowships, and the introduction of special courses on the subject into curricula.

Mr. H. G. WeLLs, president-elect of Section L (Education) of the British Association, who contributed to the discussion, thought there will be no peace in the world until education has been recast into a common basis of understanding throughout the world. He had little confidence in what has been called 'scientific' American, British, or other history. There is but one history-the history of mankind. The world is involved in great issues of human ecology and of economics, but little of these things is taught. He said that we shall have to realizeand it will be a wrench-that much of the history at present taught is stale, unprofitable and out of date. British people are curious about America. They devour American publications; they patronize American films; they are learning to think and speak American; but they are not interested in the history of the Constitution or local points of preCivil War days. The public is willing to react against limited histories and get into general understandings, but the schools hold up this natural development towards the human understanding of the world.

\section{The National Maritime Museum}

THe National Maritime Museum, opened by H.M. the King on April 27, is a notable addition to the public galleries of Great Britain. Housed in a building with historic associations from which can be seen on one side Greenwich Park and the Royal Observatory and on the other the Royal Naval College and the Thames, the Museum will make an appeal to all who take an interest in the history of naval affairs, the growth of the British Empire and the lives of great British seamen of the sixteenth, seventeenth and eighteenth century. It has come into existence through the enthusiasm of the members of the Nautical Research Society, the munificence of Sir James Caird and finally the passing of the National Maritime Museum Act of 1934. The buildings it occupies include the Queen's House finished three hundred years ago, and the wings erected during the nineteenth century when the place was used for the Greenwich Hospital School, now removed to Holbrook, Suffolk. After restoration by the Office of Works, both the Queen's House and the other buildings have been turned into galleries, which now contain the most magnificent series of sea pictures in existence. In addition to the portraits, seascapes, and battle scenes, the great Macpherson collection of prints, drawings, etc., there are beautiful models of ships of the various periods, collections of navigational instruments and a spacious library. No attempt so far has been made to illustrate the great revolution in maritime affairs during the nineteenth century or the historic events of more recent times, but these no doubt will be taken into consideration in due course. The thanks of the whole community, no less than those of students of maritime affairs and of marine art, are due to Sir James Caird, who has made the nation his debtor by the support he has given to the formation of the museum.

\section{The Newcomen Society}

ON April 21, simultaneous meetings of the Newcomen Society took place in London and New York, when two papers were read. The first of these was by Dr. A. Raistrick, and was entitled "The Steam Engine on Tyne Side, 1715-1778" and the second was by Prof. J. W. Roe on "Interchangeable Manufacture". Dr. Raistrick's paper was based on the records preserved by the North of England Institute of Mining Engineers, Newcastle-upon-Tyne; these records consisting largely of "View books" compiled by the colliery 'viewers', the forerunners of the present-day mining engineers. The reports of the 'viewers' contain much information as to the flooding in the mines and the cost of the engines and the pumping. By means of the various papers, Dr. Raistrick has been able to trace the erection of no fewer than 104 'fire engines' built between 1733 and 1778, before the improved engines of Boulton and Watt came on the scene. A rough figure for the first cost of an engine with a 33 in. cylinder was about $£ 1,200$ and the annual cost of working it $£ 400$. Though 13 engines were built between 1715 and 1733 , all of the Newcomen type, it has been impossible to 
trace any connexion with them of Newcomen or of the "Proprietors of the Invention for Raising Water by Fire" who had exploited the engine. The paper was accompanied by a valuable map of the coal field showing the sites of the engines. In Prof. Rne's paper it was shown that interchangeable manufacture had begun with firearms early in the nineteenth century and had afterwards spread to clocks, watches, sewing machines, bicycles and motor-cars. of all the products of modern industry, the motor-car has pushed interchangeable manufacture furthest, and to the benefit of the widest public.

\section{Low Temperature Carbonization Plant}

THE recent opening by the Duke of Kent of a new plant erected near Chesterfield by Messrs. Low Temperature Carbonisation Ltd. has once again directed public attention to the commercial possibilities of carbonizing coal at comparatively low temperatures (about $600^{\circ} \mathrm{C}$.). This method of treating coal has as its main product a smokeless fuel which can readily be burned in any open grate, and in consequence is a valuable contribution towards a solution of the important problem of reducing atmospheric pollution. In addition, the process yields as by-product a tar from part of which a fuel suitable for use in Diesel engines can be prepared and a motor spirit of high antiknock value. The tar is also amenable to treatment by hydrogenation for the production of further motor spirit if desired. In view of a possible national emergency, there is a tendency, particularly among those not acquainted with all the relevant details, to stress the value of low temperature carbonization as a source of homeproduced motor spirit. It is, therefore, well to bear in mind that although any method of producing oil or spirit from coal is of national importance, the spirit is in this case only a by-product, and that even if all the tar were hydrogenated to produce additional motor spirit, the total yield would be extremely small when compared with the quantity now imported.

\section{Centenary of the University of Athens}

The University of Athens is the richer to-day by the congratulations of the world of learning on its centenary. Elaborate celebrations have marked this event, which was enhanced by the active participation of H.M. the King of Greece, members of the Government, of the Church and of the Services, the French Minister of National Education, and 150 delegates representing eighty foreign universities. Eloquent addresses, official receptions, musical festivals and classical performances added to the splendour of the occasion. During the past hundred years, the University of Athens has grown from a small establishment with fourteen students, to a mighty seat of learning with nearly ten thousand students of both sexes, an imposing list of professors, and manifold extensions, laboratories and institutes as additions to the original faculties. Parallel with the development, learning has found in Athens the old spirit which made the town famous throughout the classical and Byzantine periods. To-day, science and letters are steadily pursued by a band of investigators who have made substantial contributions to knowledge. To give just one example, mathematicians are familiar with the names of Hatzidakis, Zervos, Sakellariou and Eginitis. Even the history of science is represented by Prof. Stephanidis, who has many important monographs to his credit. If the English language and literature were not hitherto adequately represented, the omission has been made good by the creation of a Byron chair, which was announced as a gift of Great Britain to the most ancient seat of learning of Western civilization.

\section{Witchcraft in Bechuanaland}

WIDESPREAD interest has been aroused by the trial for witcheraft of Bagakgametsi, the former wife of Tshekedi, son of Khama, and regent chief of the Bamangwato tribe. This chief, it will be remembered, earned notoriety a little while ago for inflicting punishment on a white man, as it was held, illegally, and was deprived of his chieftainship in consequence. In February 1936 he married his cousin, Bagakgametsi, but secured a divorce from her on March 7 of this year. She is now twenty-seven years old, and was described by Sergeant Lewis, the prosecutor in the present case at Serowe, as "an educated woman". With her were accused two men, who are described as witch-doctors. The offence alleged was "practising witchcraft calculated to injure the Queen-Mother, Semane" ; but it was asserted in evidence, as reported, that Bagakgametsi herself was in fear, or stated that she was in fear of witchcraft by the Queen Mother, and consulted her two co-defendants to verify her suspicion and secure protection. One witch doctor in giving evidence in defence stated that he blew on a horn and threw the bones - the usual divinatory procedure in such cases-and said, "If Semane is bewitching Bagakgametsi she should die from blood". He added that Semane would die within two months. The other witch doctor said that the woman came to him for medicine and said she was afraid that Semane, who was jealous of her, would kill her. On the other hand, it was alleged by the prosecution that Bagakgametsi had asked one of the men for a poison root to get rid of the Queen Mother so that she alone should share Tshekedi's power. The verdict was "guilty", and a fine of $£ 50$, or twelve months imprisonment was imposed. The case is interesting as illustrating the strong hold of a belief in witcheraft on this people, even among the more enlightened, as. well as the illogical working of the attempt to suppress. the belief, which concentrates on the witch doctor, who though in many instances undoubtedly fraudulent, is at least working against an anti-social force which in such circumstances as these goes free. The British code, however, does not recognize witchcraft. as such.

\section{Synthesis of Large Molecules}

Aт the Friday evening discourse at the Royal Institution on April 23, Prof. H. Mark discussed "The 